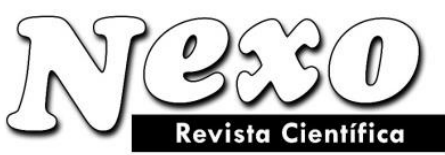

Vol. 34, No. 04, pp. 1231-1242/Septiembre 2021

\title{
Analysis success factors of the new cities establishment (case study: Pardisan town)
}

\section{Análisis de factores de éxito del establecimiento de nuevas ciudades (estudio de caso: Pardisan town)}

\author{
Narjes Ghaempanah ${ }^{1, *}$, Mohammad-Taghi Rahnamaei ${ }^{2}$ \\ ${ }^{1}$ Department of Geography, PNU Rasht Branch, Rasht, Iran. \\ ${ }^{2}$ Faculty of Geography, University of Tehran, Tehran, Iran. \\ * narjes.ghaempanah.86@gmail.com
}

(recibido/received: 15-mayo-2021; aceptado/accepted: 10-agosto-2021)

\begin{abstract}
New towns and cities are proposed as the places for absorbing the population overflow and limiting the population growth in metropolises. In Iran, these towns and cities are built very close to the metropolises, and gradually, they are being used only as dormitories. The new town of Pardisan is built 13 kilometers southwest of Qom as the largest new town of the urban district of Qom in order to organize the residence system and absorb the population overflow of the metropolis of Qom and reduce its problems. This paper studies the function of the Pardisan new town as the absorber of the population overflow of Qom and also the residents' satisfaction with this town. The research method adopted by this study is based on the library, documentary, and field data, and also interviews and collection of data by questionnaires and TOPSIS model. The results of this research indicate that many of the families living in the Pardisan town constitute the population overflow of the metropolis of Qom; Among the most important reasons for the migration of families to the Pardisan town is the low cost of land and residence, and 4.67 percent of the residents do not like to live in this town. This unsuccess is mostly due to lack of job and activity in this town, and therefore, the residents are less satisfied with the town.
\end{abstract}

Keywords: New Towns, Success Analysis, Resident Satisfaction, Pardisan Tow

\section{RESUMEN}

Se proponen nuevos pueblos y ciudades como lugares para absorber el desborde poblacional y limitar el crecimiento poblacional en las metrópolis. En Irán, estos pueblos y ciudades se construyen muy cerca de las metrópolis y, gradualmente, se están utilizando solo como dormitorios. La nueva ciudad de Pardisan se construye a 13 kilómetros al suroeste de Qom como la ciudad nueva más grande del distrito urbano de Qom para organizar el sistema de residencia y absorber el desbordamiento de población de la metrópoli de Qom y reducir sus problemas. Este artículo estudia la función de la nueva ciudad de Pardisan como absorbente del desbordamiento de población de Qom y también la satisfacción de los residentes con esta ciudad. El método de investigación adoptado por este estudio se basa en la biblioteca, documental y datos de campo, así como entrevistas y recolección de datos mediante cuestionarios y modelo TOPSIS. Los 
resultados de esta investigación indican que muchas de las familias que viven en el pueblo de Pardisan constituyen el desbordamiento de población de la metrópoli de Qom; Entre las razones más importantes para la migración de familias al pueblo de Pardisan está el bajo costo de la tierra y la residencia, y al 4,67 por ciento de los residentes no les gusta vivir en este pueblo. Este fracaso se debe principalmente a la falta de trabajo y actividad en esta ciudad, y por lo tanto, los residentes están menos satisfechos con la ciudad.

Palabras clave: Ciudades nuevas, Análisis de éxito, Satisfacción de los residentes, Pardisan Tow

\section{INTRODUCTION}

The growth of the urban system and the increment of urbanization in this age are the results of the development of industry and technology which led to the creation of metropolises. In different periods, towns are created with different purposes in different places of the world, and they can be called new towns (Rahnamaei, 2008, 20). New towns are born on a specific date, and they are built in a particular and short time. The necessity for the foundation of new towns and cities arises because of the rapid urbanization and the wave of the villagers' migration to the cities and consequently, the appearance of the areas with improper residential circumstances due to unreadiness of the social conditions of the developing countries. In a specific period of their development and centralization, metropolises started to refine the functions due to the increment of the costs resulted from high density and mass. They scattered a portion of the functions (activities) together with the population in the surrounding spaces (Zebardast, 2007, 84). In fact, the concept of new town is in an organic relationship with the concept of the city components (Shin 2012, 91). To provide people with a systematic residence in Iran, the ministry of housing and urban development is directly responsible for the residential policies and takes measures to locate and build new towns (Ebrahimzadeh et al. 2004, 28). There are currently various points of view held about the success or unsuccess of this solution. In such kind of situation, it seems necessary to analyze the function of these towns and revise this policy according to the results.

The city of Qom has recently faced the uncontrolled growth of the city's population and according to the population estimates, the population of the city will reach $1,454,215$ in 2021 . This city is the main center of the population hinterlands of the whole province. The total population of the province of Qom stands at 1,632,509 (Qom structural plan 2003, 42). Now, most of the province's people live in the city of Qom and the other existing cities cannot compete with it. Consequently, due to the imposed heavy population load, this city will be inevitably expanded, and this problem arises the necessity of the creation of new towns in this province (Ahmadi Shapouarabad, 2007, 85). The policy of the continuous urban development adopted in the detailed plan of Qom has led to the expansion of Qom towards its southwestern side. Consequently, the 1000-hectare lands of Pardisan being situated on the southwestern side of Qom, are considered as the future expansion of the city in the comprehensive plan (detailed plan of Pardisan, 2006,25).

Today, Qom is one of the ten metropolises of Iran and according to a survey conducted in 2016, Qom is the seventh highly populated city of Iran. This city is considered to be important because it is situated between two greater cities, it is a place of pilgrimage and the center of the Shi' ite religious reference. But the highest point of its development is about the time when in 1997, it was changed into a province with its center as Qom. Qom is somewhat a single-city province, however, according to political-official regulations, there are other cities considered as urban points in this province. Making up 97 percent of the population of the province, Qom is the largest city in that area. The largest new town of Qom, namely, the Pardisan town was chosen among other towns such as Qods, Koye Farhangian, Mahdiye, Salafchegan, Mahmoud Abad, and Shokouhiye to analyze its success in the decentralization of the metropolis of Qom and also to analyze the residents' satisfaction with this town. 


\section{THEORETICAL FOUNDATION AND LITERATURE REVIEW}

The official theory of the creation of new satellite towns was first introduced by Leonardo da Vinci in order to prevent the growth of the population in Milan and to solve urban problems (Azani et al. 2009, 27). The theory of new towns is actually inspired by various ideas. Its main theoretician was Ebenezer Howard, the English man. Howard proposed his theory as the "Garden City Movement" (Habibi, 2013,126) Pierre Merlin believes that functionally, the new residential towns are one of the three main new grous of cities in the world. These cities are designed based on the policies of urban development, and they are mostly created to spread the population density and activities from large cities and to provide people with a place of residence. The migration of villagers to the cities, the growing urban population of Iran, and the increment of the number of the cities had led to the point that in order to solve the problem of large cities and to absorb the population overflow of metropolises, new towns were built around big cities. This idea was offered in 1984 (Zebardast, et al. 2007, 17). Therefore, the number of the new towns that their places were approved by the supreme council of urban planning and architecture of Iran from 1986 to 1991 was 23 among which only 18 towns went through the process of construction (Behzadfar, 2019, 100). Various research and studies conducted regarding the new towns in Iran indicate that these towns could not effectively absorb the extra population of their metropolises, and very few people live in them (Shams et al. 2016, 91). But in fact, the responsibility of new towns is to develop the districts socially and economically and to provide the areas under the influence of the cities with services so that these new towns will not turn into soulless dormitory towns. (Bazzi 2009,34).

One of the indicators of the success of new towns is that the reasons for migrating to them should be in accordance with their goals and programs. Shokouei believes that the economic factor is very important when one is to choose a residential district and it plays an important role not only concerning the price of land, house, and renting, but also it is effective in choosing the residential area that is close to the workplace (Taghvaei, 2011,60) Time and cost of commuting are also factors that influence the choice of residential place (Etaat, 2010,39). A new town is a town that is not dependent on the metropolis in terms of employment and to some extent services. Some pieces of research show that an important reason for the development of the satellite towns around the metropolises is the emigrants who seek better living conditions outside the cities (Akrami, 2012, 49). The number of people absorbed by the new towns is in relationship with people's beliefs, how the applicants react, the desirability of urban services, and how the construction of the new towns progresses (Gharakhloo et al., 2009, 12). On the other hand, when people take up residence in the new town, they expect the whole services, simultaneously and in high quality (Ghasemi, 2016, 163). It means that the applicant of the lands and houses of the new towns do not necessarily want to live there with any possible circumstance, but they require the minimum urban equipment and facilities, proper housing, and public and welfare services (Iranshahi et al. 2017, 15). The absorption of the population is not enough for new towns, but it is really important to keep the emigrants in these towns. Here, the tendency to stay in the town and satisfaction with coming to these towns are important indicators (Harirchi, 2009, 100).

The studies conducted by Berry and Quesarda show that an important factor affecting the choice of residential units is the price of residential units and rent which depends on the income of the individual or families. In a paper titled "A study of commuting patterns of new town residents in Hong Kong", the results showed that despite the ideals imagined in the program principles of new towns, improper vocational and educational conditions of these towns have led to daily trips from new towns to the old cities (Hui, 2016, 74). The research conducted by Burby and Weiss shows that an important factor that makes people satisfied with new towns is the satisfaction of the major goals that families are trying to achieve by moving to a new town (Burby and Weiss, 2007, 105). According to Johnston, when moving to a new place, the distance from the everyday workplace and being close to relatives and acquaintances are essential factors in the choice of the residential area (Johnston, 2011, 243). 
Ghorbani In the paper "Analysis of the process of the population absorption of the Sahand new town and the need for a comprehensive revision of housing policies in Tabriz urban area", concluded that the analysis of the suggested program of the Sahand new town and their comparison with the existing conditions of the urban areas of Tabriz shows some errors in the achievement of the goals of this program. In another research titled "New towns and their practical challenges: the case of Fooladshahr in Iran", the district of Isfahan and its new towns, the comprehensive plan of Fooladshahr and its development and practical challenges were studied, and it was concluded that Fooladshahr has a long way to become a new dynamic, balanced, and independent town (Varesi et al. 2011, 45). In the paper "A survey about Hashtgerd new city operation in surplus population attraction", Zebardast concluded that although the new town of Hashtgerd is behind the planned schedule, its predicted role and function concerning the absorption of the population overflow of the metropolis of Tehran and Karaj and supplying residents (despite its slow process) is being relatively realized. Ghasemi et al. (2016) in their paper "Evaluation of quality of life in new towns using subjective quality assessment" analyzed the city of Hashtgerd and concluded that the residents are not well satisfied with the environmental quality, and the duration of residence, gender, marital status, in contrast with the variables of age and education are the factors influencing the satisfaction of residents.

\section{RESEARCH AREA}

In 1997, According to the invitation letter No.1111, dated February 12, 1997, from the housing and urban development organization of Qom province, the meeting of the article 5 commission of the city of Qom was held on February 13, 1997, in the Qom provincial government office. Also in the development and civil plan of the city of Qom that is approved by the supreme council of urban planning and architecture (Bavand consultants), the lands of Pardisan are situated in the protected area of Qom. The preparation plan of the Pardisan's lands in Qom (that was first called the plan of the preparation of the lands of the spot flat area of Qom) is considered as one of the preparation plans of the land with an area of 1000 hectares that is designed and prepared to meet the future need of residence in Qom. The contract of the preparation of the primary design of the Pardisan town was sent to the consultants by housing and urban development organization in 1997. In 1998, it was revised and approved by Farnahad consultants (Pardisan detailed plan, 2007, 112).

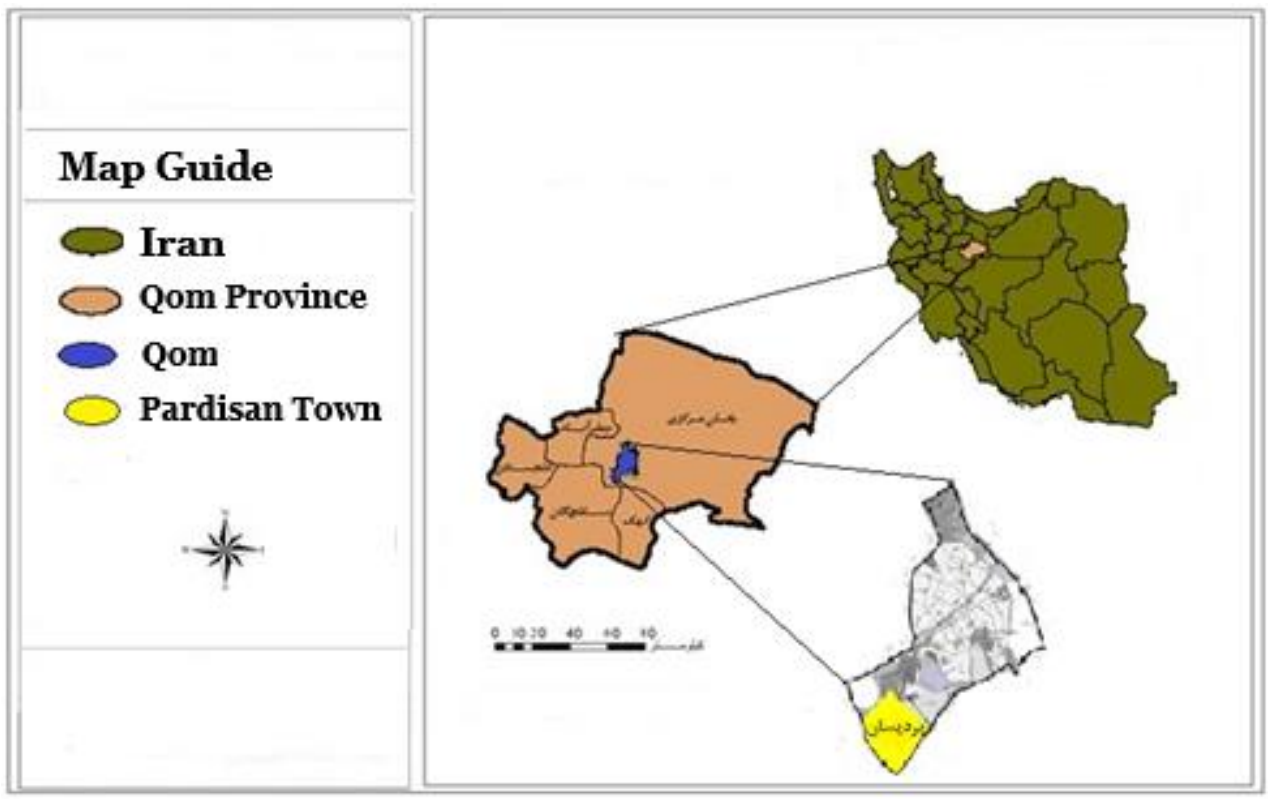

Figure 1: The location of the province of Qom, city of Qom, and Pardisan town 
The Neyzar road is on the western side of these lands which generally connects the land with the city center, and in the future expansion of the city is the vital and prime road. With a width of 8 meters, this asphalt road connects the city of Qom to the cities of Delijan and Isfahan, and it is called the old road of Isfahan. The town of Mahdiye is located on the northern side of these lands. The main connection of this town with the Pardisan lands is currently through the Neyzar road. There are some low hills between the Mahdiye town and the lands of Pardisan that are near to the latter. The Qom river is on the western side of the lands approximately in parallel with the Neyzar road. The fan manufacturing company is situated on the southwestern lands and outside the area. In terms of natural conditions, Pardisan's climate is more favorable than Qom's. Sometimes its temperature drops to several degrees. The land slope is approximately 2.1 percent along the Qom river, from southeast to northwest. The reasons for locating the town of Pardisan in these lands are: The more favorable climate in comparison with the city of Qom due to the southwestern mountains, adjacency to the main road of Isfahan, these lands were not fertile and were suitable for town construction, flat morphology, proper conditions of wastewater disposal, low-level groundwater, and low risk of earthquake. In the preparation plan, the lands were divided into three urban are. These areas were divided into 6 districts and 15 neighborhoods along with two neighborhoods with areas of approximately 117 hectares. These were according to previous preparations, and three districts including 11 neighborhoods are constructed recently and two other neighborhoods are related to the new plan. In 2016, of the total population considered for the 883-hectare area, 12029, 35154, and 88197 people were programmed respectively for the low, medium, and high density. Until now, 4830, 8232, and 19862 people are settled respectively as low, medium, and high density. Therefore, of the total 135380 people, 32924 are considered to be the settled population and the other 102456 will settle based on the schedule. Based on the entry and exit statistics of the town collected by the public relations office of the new town civil firm, in 2016, the new town of Pardisan had a population of about 32,000 of which 10, 18, and 4 thousand people lived respectively in phase one, two, and three.

Table 1: Predicted population distribution and density in Pardisan urban areas up to 2021

\begin{tabular}{|c|c|c|c|c|}
\hline Description & Population (person) & Gross density & Net density & Residential per capita \\
\hline District 1 & 23219 & 105.76 & 457.9 & 21.84 \\
\hline District 2 & 2005 & 102.91 & 458.7 & 21.8 \\
\hline District 3 & 24655 & 220.3 & 425.1 & 23.5 \\
\hline District 4 & 37668 & 208.3 & 441.8 & 22.6 \\
\hline District 5 & 16374 & 164.5 & 336.3 & 29.7 \\
\hline District 6 & 31222 & 207.8 & 445.9 & 22.4 \\
\hline 117-hectare & 17957 & 164.5 & 310.3 & 32.4 \\
\hline Sum & 153100 & 157.9 & 410.4 & 24.37 \\
\hline
\end{tabular}

Reference: Detailed plan of Pardisan, 2006

Table 2: Land use area of the Pardisan town in the current state

\begin{tabular}{|c|c|c|}
\hline Type of use & Area (square meters) & Percentage \\
\hline Residential & 1080372.7 & 60.5 \\
\hline Higher education & 504463.8 & 28.5 \\
\hline Cultural-religious & 48360.1 & 2.8 \\
\hline Educational & 30166.2 & 1.8 \\
\hline Official-disciplinary & 64185.8 & 3.7 \\
\hline Sanitary-medical & 24628.6 & 1.5 \\
\hline Green space & 6938.2 & 0.40 \\
\hline Sports & 20795.9 & 1.1 \\
\hline Commercial & 3490.2 & 0.20 \\
\hline Transportation & 369.3 & 0.03 \\
\hline
\end{tabular}

Reference: Housing and urban development organization of Qom, 2017 
Table 3: Land use in the suggested plan of the Pardisan town

\begin{tabular}{|c|c|c|}
\hline Use & Level & Per capita \\
\hline Residential & 3852812 & 24.4 \\
\hline Commercial & 175150 & 1.1 \\
\hline Educational & 302531 & 1.9 \\
\hline Higher education & 605063 & 3.8 \\
\hline Cultural & 111459 & 0.7 \\
\hline Religious & 30253 & 0.19 \\
\hline Catering-tourism & 63691 & 0.4 \\
\hline Medical-sanitary & 63691 & 0.4 \\
\hline Official-disciplinary & 216549 & 1.36 \\
\hline Sports & 127382 & 0.8 \\
\hline Green space & 1226048 & 7.7 \\
\hline Workshop & 79614 & 0.5 \\
\hline Facilities and equipment & 98721 & 0.62 \\
\hline Parking & 135343 & 0.85 \\
\hline Social & 39807 & 0.25 \\
\hline Green zone & 226102 & 1.42 \\
\hline Passages & 2724612 & 17.11 \\
\hline Sum & 10078828 & 63.5 \\
\hline
\end{tabular}

Reference: Detailed plan of Pardisan, 2006

\section{DATA AND METHOD}

The questionnaires were the tools for the collection of data in the field studies of this research. First, by using the Cochran formula, the sample size 300 was calculated with a coefficient error of 5.0. Then, the multistage sampling method was used in this way: The cluster random sampling method was used to choose the samples according to the detailed plan of Pardisan and based on the divided phases 1,2, and 3 . Each phase is considered as a major cluster and in each cluster, each block or neighborhood is considered as a minor cluster based on their division system. Then, based on the approximate number of residents and the number of residential units, some of the residential units were chosen as the sample in each minor unit (block or neighborhood) by the systematic sampling method. Based on the population of the residents in each phase, of 300 questionnaires, 100, 185, and 15 questionnaires were distributed respectively in phases one, two, and three. For the assessment of data, scoring was done by Likert scale and for the calculation, the TOPSIS method was used. In order to achieve the study goals, the questions of the questionnaire were designed based on the required factors. Also, for defining the qualitative values, quantitative domains were considered for comparisons.

Table 4: Assessment variables and methods in accordance with the research goals

\begin{tabular}{|c|c|c|c|c|}
\hline No. & Goals & Related variables & Assessment & $\begin{array}{l}\text { Domains for } \\
\text { comparison }\end{array}$ \\
\hline 1 & $\begin{array}{l}\text { Investigating the } \\
\text { former residence } \\
\text { place of the } \\
\text { residents in Pardisan } \\
\text { town }\end{array}$ & $\begin{array}{l}\text { Qom, Qom cities, Qom } \\
\text { villages, former } \\
\text { residence place of the } \\
\text { family, duration of } \\
\text { residence in the former } \\
\text { residence place and in } \\
\text { the new town of Pardisan }\end{array}$ & $\begin{array}{l}\text { Frequency percentage } \\
\text { of the families } \\
\text { That their former place } \\
\text { residence was Qom }\end{array}$ & $\begin{array}{l}0-20 \text { percent, very low } \\
20-40 \text { percent, low } \\
40-60 \text { percent, medium } \\
60-80 \text { percent, high } \\
80-100 \text { percent, very } \\
\text { high }\end{array}$ \\
\hline 2 & $\begin{array}{l}\text { Investigating the } \\
\text { most important }\end{array}$ & $\begin{array}{l}\text { The reasons why } \\
\text { families come to }\end{array}$ & $\begin{array}{l}\text { Frequency percentage } \\
\text { of the response "low }\end{array}$ & $\begin{array}{l}0-20 \text { percent, very low } \\
20-40 \text { percent, low }\end{array}$ \\
\hline
\end{tabular}




\begin{tabular}{|l|l|l|l|l|}
\hline & $\begin{array}{l}\text { reasons why } \\
\text { residents move to } \\
\text { the new town of } \\
\text { Pardisan }\end{array}$ & Pardisan town & $\begin{array}{l}\text { cost } \\
\text { residence" in all } \\
\text { samples. }\end{array}$ & $\begin{array}{l}\text { 40-60 percent, medium } \\
\text { 60-80 percent, high } \\
80-100 \text { percent, very } \\
\text { high }\end{array}$ \\
\hline \multirow{2}{*}{3} & $\begin{array}{l}\text { Investigating the } \\
\text { intention and } \\
\text { tendency of the } \\
\text { residents to stay in } \\
\text { the town and their } \\
\text { satisfaction with } \\
\text { moving to the town }\end{array}$ & $\begin{array}{l}\text { Intention to stay in } \\
\text { Pardisan, Tendency to go } \\
\text { to another place, } \\
\text { destination for moving, } \\
\text { level of satisfaction with } \\
\text { the current and former } \\
\text { residential place }\end{array}$ & $\begin{array}{l}\text { Frequency percentage } \\
\text { of satisfaction with } \\
\text { previous place of } \\
\text { residence and desire to } \\
\text { leave Pardisan (Scoring } \\
\text { by the method of Likert } \\
\text { scale and calculating by } \\
\text { the TOPSIS method) }\end{array}$ & $\begin{array}{l}\text { 0-0.2= Very low } \\
2.0-4.0=\text { Low } \\
4.0-6.0=\text { Medium } \\
6.0-8.0=\text { High } \\
8.0-10.0=\text { Very High }\end{array}$ \\
\hline
\end{tabular}

\section{RESEARCH FINDINGS}

Based on the main goal of this research that is the analysis of the function of Pardisan in relation to the population absorption of the urban district of Qom, by investigating the data concerning the former residence place of the sample families based on the questionnaire results, it was recognized that 4.71 percent (the frequency of 214 people) of these families have moved to this town from the city of Qom. This portion constitutes the majority of the emigrants to the Pardisan town. According to the point that a considerable number of Pardisan's residents have migrated from the city of Qom to this town, by improving the current situation of the new town, more people could be always absorbed from the metropolis of Qom and kept in the town. Also, 1.5 percent of residents have migrated from other cities of Qom province, 3.4 percent from villages of Qom province, and 2.19 percent from other provinces. By comparing the total values of this variable with the domains mentioned in Table 4 it is recognized that "many of the residents of the Pardisan town constitute the population overflow of the metropolis of Qom".

Table 5: The distribution of families based on their former residences

\begin{tabular}{|c|c|c|}
\hline Former residence & Frequency & Percentage \\
\hline Qom & 214 & 71.4 \\
\hline The cities of the Qom province & 15 & 5.1 \\
\hline The villages of the Qom province & 13 & 4.3 \\
\hline Out of the Qom city & 58 & 19.2 \\
\hline Sum & 300 & 100 \\
\hline
\end{tabular}

In order to analyze the second goal namely, the most important reasons why the residents have migrated to the Pardisan town, the data collected by the questionnaires were assessed and they showed that among the mentioned reasons, the most frequency percent, namely, 2.45 belongs to the reason "low cost of houses" in this town and in the next level, there is the reason "low rent cost" with 8.31 percent. Also, no family has migrated to the Pardisan town for better employment. Other collected data are shown in figure 2 and 3. The system of housing and land distribution in Pardisan is arranged in a way that most of the people of middle classes and the classes lower than the middle tend to live in Pardisan according to economic conditions and the land value and also the final price of houses in this town in comparison with the same condition in the metropolis of Qom. 


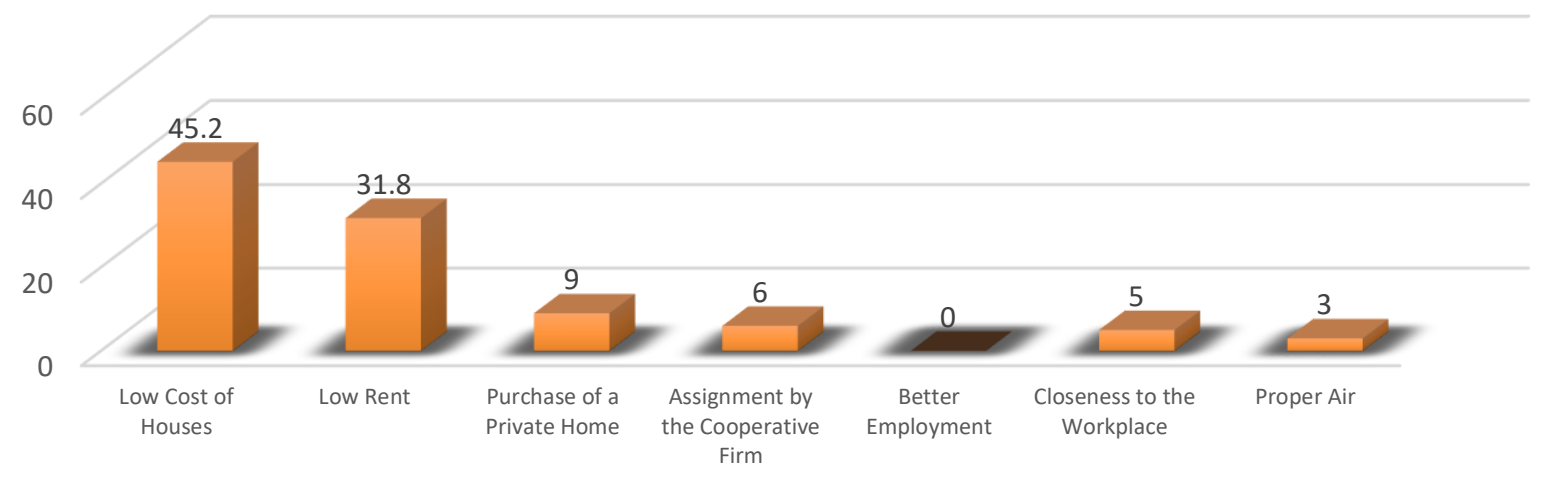

Figure 2: The most important reasons for moving to the Pardisan town

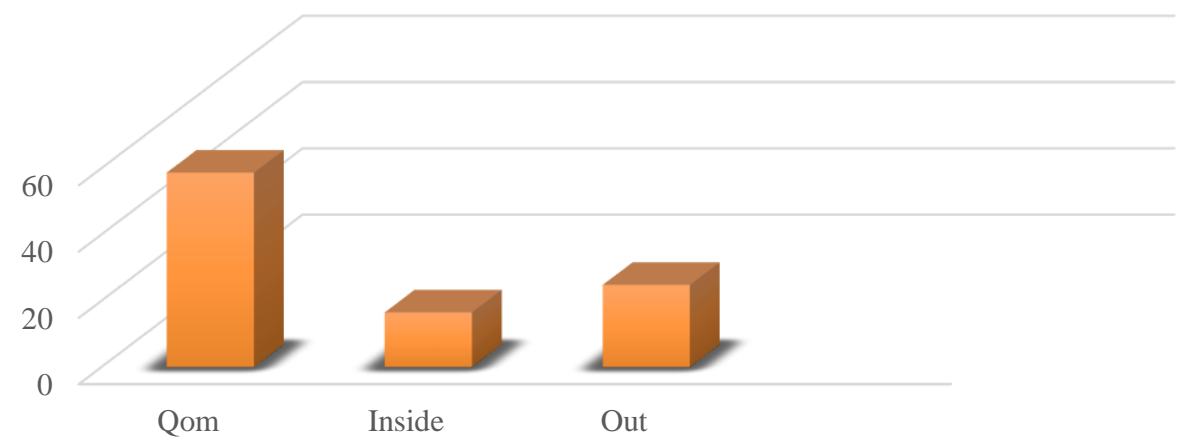

Figure 3: Distribution of sample families based on the tendency to move to the place they like (percentage)

Table 6: The reason for the migration of residents from former place to the current residence place

\begin{tabular}{|c|c|c|}
\hline Cause of migration & Frequency & Percentage \\
\hline Low Cost of Houses & 136 & 45.2 \\
\hline Low Rent & 95 & 31.8 \\
\hline Purchase of a Private Home & 28 & 9.3 \\
\hline Assignment by the Cooperative Firm & 18 & 6.1 \\
\hline Better Employment & 0 & 0 \\
\hline Closeness to the Workplace & 17 & 5.5 \\
\hline Proper Air & 6 & 2.1 \\
\hline
\end{tabular}

In the established new towns, it is not sufficient to attract and families and absorb the population by promises and programs which are not going to be fulfilled, but it is very important to keep the residents and satisfy their needs (Kheiredin, 2016, 53) Therefore, the analysis of the satisfaction of residents can reveal many problems existing in these towns. After that residents are settled in the new town, they require all services simultaneously and in a higher quality than their former city or metropolis (Ebrahimzadeh et al. 2009, 158). Therefore, the low cost of land and houses in the new town will not satisfy families, but also they require urban facilities and equipment, the transportation system, public services, welfare services, and so on (Gharakhloo et al., 2009, 19), In order to achieve the third goal, namely, "the analysis of the satisfaction of residents in the Pardisan new town", the satisfaction and tendency of people to live in Pardisan was assessed by the data collected through questionnaires including the questions about urban functions. Also, other variables concerning the satisfaction of residents, such as gradual reduction of 
problems, available facilities and services required by residents, meeting the needs of residents and so on are shown in table 7.

Table 7: Analysis of the variables affecting the level of the satisfaction of Pardisan's new town

\begin{tabular}{|c|c|c|c|c|c|c|c|}
\hline $\begin{array}{l}\text { The domains of the comparison of } \\
\text { variables }\end{array}$ & $\begin{array}{l}\text { Frequency } \\
\text { Percentage }\end{array}$ & $\begin{array}{l}\text { Very } \\
\text { Low }\end{array}$ & Low & Medium & Much & $\begin{array}{l}\text { Very } \\
\text { Much }\end{array}$ & Sum \\
\hline \multirow{2}{*}{$\begin{array}{l}\text { The effect of the closeness to the } \\
\text { workplace for choosing the Pardisan town }\end{array}$} & Per. & 34.5 & 37.2 & 18.6 & 9.7 & - & 100 \\
\hline & Frq. & 104 & 112 & 56 & 28 & - & 300 \\
\hline \multirow{2}{*}{$\begin{array}{l}\text { Available facilities and services required } \\
\text { for the residents in the Pardisan town }\end{array}$} & Per. & 8.5 & 33 & 48.3 & 10.2 & - & 100 \\
\hline & Frq. & 25 & 99 & 145 & 31 & - & 300 \\
\hline \multirow{2}{*}{$\begin{array}{l}\text { Gradual reduction of the problems in the } \\
\text { new town }\end{array}$} & Per. & 11.4 & 50.1 & 27.4 & 11.1 & - & 100 \\
\hline & Frq. & 34 & 150 & 83 & 33 & - & 300 \\
\hline \multirow{2}{*}{$\begin{array}{l}\text { Assessment of the sense of spatial } \\
\text { belonging of residents to the Pardisan } \\
\text { town }\end{array}$} & Per. & 15.5 & 37.8 & 26.6 & 15.6 & 4.5 & 100 \\
\hline & Frq. & 46 & 113 & 80 & 47 & 14 & 300 \\
\hline \multirow{2}{*}{$\begin{array}{l}\text { Meeting the needs of the residents by the } \\
\text { Pardisan town }\end{array}$} & Per. & 9 & 35.5 & 37.9 & 17.6 & - & 100 \\
\hline & Frq. & 27 & 106 & 114 & 53 & - & 300 \\
\hline \multirow{2}{*}{ Satisfaction with living in Pardisan } & Per. & 5.3 & 13.2 & 48.8 & 21.8 & 11.9 & 100 \\
\hline & Frq. & 15 & 40 & 143 & 66 & 36 & 300 \\
\hline
\end{tabular}

In order to analyze the tendency to stay in the town, the data collected by the questionnaires about the satisfaction with former and existing residence places was used to investigate "the satisfaction with living in the Pardisan town", and "gradual reduction of problems" among the sample families as follows:

Table 8: The distribution of the sample families based on the intention and tendency to stay in the Pardisan town

\begin{tabular}{|c|c|c|}
\hline Satisfaction with the current or former residence place & Frequency & Percentage \\
\hline We will leave as soon as possible & 202 & 67.4 \\
\hline We are not going to stay & 39 & 12.6 \\
\hline Not specified & 59 & 20 \\
\hline Sum & 300 & 100 \\
\hline
\end{tabular}

Table 9: The distribution of the sample families based on their viewpoint about the reduction of problems over time

\begin{tabular}{|c|c|c|}
\hline Reduction of problems over time & Frequency & Percentage \\
\hline Very low & 11.4 & 34 \\
\hline Low & 50.1 & 150 \\
\hline Medium & 27.4 & 83 \\
\hline High & 11.1 & 33 \\
\hline Very high & - & - \\
\hline Sum & 100 & 300 \\
\hline
\end{tabular}

Table 10: The distribution of the sample families based on the level of satisfaction with living in the Pardisan town

\begin{tabular}{|c|c|c|}
\hline Satisfaction with living in Pardisan & Frequency & Percentage \\
\hline Yes & 72.7 & 218 \\
\hline Abstention & 9 & 27 \\
\hline No & 18.3 & 55 \\
\hline Sum & 100 & 300 \\
\hline
\end{tabular}

Scoring by Likert scale method (The sum of frequency percentage of each option):

- Satisfaction with the current or former residence place (1 not specified 2 we will stay 3 we will leave)

- Reduction of the Pardisan's problems over time (1-Very low 2-Low 3-Medium 4-High)

The level of satisfaction with living in the Pardisan town (1- No 2-Abstention 3-Yes) 
In the TOPSIS method, $\mathrm{v}^{+}$is the positive ideal vector, $\mathrm{v}^{-}$is the negative ideal vector, and $\mathrm{v}$ is the existing condition vector. By calculation of the distance of $\mathrm{v}$ from $\mathrm{v}^{+}$, the value $\mathrm{d}^{+}$and by the calculation of the distance of $\mathrm{v}$ from $\mathrm{v}^{-}$the value $\mathrm{d}^{-}$will be achieved. The value of $\mathrm{R}$, namely the distance between the current condition from the two negative and positive ideal states will be calculated by the formula $\mathrm{R}=$ $d^{-}\left(d^{-}+d^{+}\right)^{-1}$ which will be the values $0 \leq R \leq$. The more the value of $R$ tends to zero, it indicates the tendency of the current state to the negative ideal, and conversely, the more the value of $\mathrm{R}$ tends to one it indicates the tendency of the current state towards the positive ideal.

Application of the TOPSIS model:

$$
\begin{gathered}
v^{+}=\left(\begin{array}{l}
300 \\
400 \\
300
\end{array}\right) \quad v^{-}=\left(\begin{array}{l}
100 \\
100 \\
100
\end{array}\right) \quad v=\left(\begin{array}{l}
247.4 \\
238.2 \\
254.4
\end{array}\right) \\
d_{j}^{+}=\left\{(247.4-300)^{2}+(238.2-400)^{2}+(254.4-300)^{2}\right\}^{\frac{1}{2}}=176.14 \\
d_{j}^{-}=\left\{(247.4-100)^{2}+(238.2-100)^{2}+(254.4-100)^{2}\right\}^{\frac{1}{2}}=254.29 \\
\mathrm{R}=\frac{254.29}{254.29+176.14}=0.59
\end{gathered}
$$

By comparing the amount of this distance by the domains mentioned in table 3, it will be recognized that the intention and tendency of the families to stay in the Pardisan town is moderate.

\section{CONCLUSION}

New towns (as they are called today) are a kind of response to concentration and overcrowding in large cities. Therefore, it can be said that the main responsibility of these towns is the decentralization and absorption of the population overflow of the metropolises and reducing their active load in order to improve the life quality and organize the population and activities in the urban districts (Monavvari et al. $2005,8)$. The analysis and evaluation of the results from the function of new towns and cities show the unsuccess and relative success of these towns and cities in the absorption of the population (Farhoudi et al. 2010, 56). Generally, the new towns built in Iran or those that are being built only meet the dormitory needs of the employees of large cities (Varesi et al. 2008, 51). These cities were not only founded without economic, social, and also occupational functions but also they could not help the dense metropolises; therefore, they have not played the expected role of absorbing the surplus population of the metropolises and they have not created a spatial balance. Generally, the policy of new towns in Iran has been unsuccessful (Iranshahi et al. 2017, 17).

This paper tried to analyze the absorption of the population overflow of the metropolis of Qom, the important reasons for migration, the level of the satisfaction of Pardisan's residents, and their intention and tendency to stay. The findings of this research show that approximately, half of the families living in the Pardisan town constitute the population overflow of Qom and one reason why families migrate to Pardisan is the low cost of residence in this town, and also the level of satisfaction of the families living in Pardisan with moving to the city is lower than the moderate and the intention and desire of the residents to stay is low. Based on the findings of the research, although the predicted process of the absorption of the population overflow is being realized slowly, there exists a defective cycle in the process that exacerbates the problems of the new towns, including the Pardisan town. It means that for creating a new town, it is required to provide employment and services, but if there is not enough employment, definitely, the population will not be absorbed by the new town enough and the population thresholds for the formation of services will not be created.

In general, it can be said that the Pardisan town is behind its approved schedule in terms of the absorption of the population. The Pardisan town has worked properly in terms of providing residence and land at 
affordable price, even this is true about its relation to the population overflow of its metropolis, but without considering the infrastructures and civil activities and lack of employment of residents, the town conditions will result in a situation in which 58 percent of the residents would desire to live in the metropolis, therefore, in order to keep the absorbed population and make the town more absorbing, some essential planned and approved actions must be carried out

\section{REFERENCES}

Ebrahimzadeh, Isa; Negahban-Marvi, Mohammad (2004), An Analysis of Urbanization and the Status of New Cities in Iran, Geographical Research Quarterly, No. 75, pp. 172-152. In Persian

Ebrahimzadeh, Isa; Gharkhloo, Mehdi (2009), An Analysis of the Role of the New Campus City in Decentralization of the Mother City of Tehran, Geography and Development, No. 15, pp. 46-27. In Persian

Ahmadi Shapour-Abadi, Mohammad Ali (2007), Qom in the Path of Development (Economic, Social and Cultural Report of Qom Province), Nedaye Elahi Publications, Qom, Iran. In Persian

Azani, Mehri; Nili Ahmadabadi, Somayeh (2009) The Influence of New Continuous Cities in Organizing the Mother City of Isfahan; Case Study: Isfahan and Malekshahr House, Geographical Space, No. 27, pp. 23-54. In Persian

Etaat, Javad (2010), Decentralization and Sustainable Development in Iran, Human Geography Research, No. 71. pp. 34-51. In Persian

Akrami, Parviz (2012), Study of Social Indicators of Population and Housing in Qom City, Qom Housing and Urban Development Organization. In Persian

Iranshahi, Ayoub; Dalake, Hasan; Samareh, Hossein (2017), Assessing Spatial Quality in New Cities Using AHP Hierarchical Analysis Process Model Case Study: Baharestan New City, Environmental Management Quarterly, No. 36, pp. 23-21. In Persian

Bazzi, Khodarham (2009), Measuring and Evaluating the Success and Efficiency of New Cities (Case study of Sadra New City), Urban and Regional Studies and Researches, No.2, pp. 49-28. In Persian

Behzadfar, Mustafa; Loghman, Mona (2019), The Effect of Social Capital Components on Quality of Life Satisfaction in Urban Areas, Social Science Studies, No. 62, pp. 123-99. In Persian

Taghvaei, Massoud; Saberi, Hamid (2010), An Analysis of Urban Systems in Iran from 1335 to 1385, Urban and Regional Studies and Research, Volume 3, Issue 7, pp. 76-55. In Persian

Habibi, Mohsen (2013), Urban Planning: Imaginations and Realities, Sixth Edition, Tehran: University of Tehran Press.

Harirchi, Amir Mahmoud; Mirzaei, Khalil; Jahromi, Azam (2009), How the Quality of Life of the Citizens of the New City of Pardis, Social Research Quarterly, Volume 7, Issue 14, pp. 110-89. In Persian

Kheiredin, Reza; Hakimzadeh Asl, Vahid (2016), Application of the Integration Model of Housing and Employment System in Assessing the Spatial Balance of New Urban Cores (Case Study: New Campus City in Tehran), Spatial Planning, Volume 20, Number 4, pp. 70-49. In Persian

Rahnamaei, Mohammad Taghi (2008), Collection of Topics and Methods of Urban Geography, Tehran: Housing and Urban Development Organization.

Zebardast, Esfandiar (2007), A Study of the First Urban Developments in Iran, Fine Arts, No. 29, pp. 76-93. In Persian 
Zebardast, Esfandiar; Jahanshahloo, Laia (2007), A Study of the Performance of the New Hashtgerd New City in Attracting Population Overflow, Geography and Development, No. 10, pp. 5-22. In Persian

Detailed plan of Pardisan (2006), Farnhad Consulting Engineers, Qom Housing and Urban Development Organization. In Persian

Qom Development, Civilization and Influence Plan (1997), Bavand Consulting Engineers, Tehran: General Department of Housing and Urban Development. In Persian

Structural-Strategic Plan of Qom City (2003), Amco Iran Consulting Engineers, Qom Housing and Urban Development Organization. In Persian

Shams, Majid; Malek Hassani, Omid (2016), Investigating the Necessity of Building a New City Around Kermanshah, Journal of Human Geography, No. 3, pp. 89-99. In Persian

Farhoudi, Rahmatullah; Zanganeh Shahraki, Saeed; Saed, Ramin (2010), How the Spatial Distribution of Population in the Urban System of Iran During the Years 1335 to 1385, Human Geography Research, No. 68, pp. 68-55. In Persian

Ghasemi, Akram; Nouri, Zahra (2016), Assessing the Quality of Life in New Cities Using Mental Quality Assessment (Case study: Hashtgerd New City), Journal of Urban Research and Planning, Volume 7, Issue 25, pp. 172-159. In Persian

Ghorbani, Reza (2007), Evaluation of Factors Affecting the Population of Sahand New City, Collection of Articles on New Cities, New Culture in Urbanism, Presented at the New Cities Seminar-Isfahan, Tehran, New Cities, pp. 143-124. In Persian

Gharakhloo, Mehdi; Abedini, Asghar (2009), Evaluating the Challenges and Problems of New Cities and Their Success Rate in Iran (Sahand New City), Modares Quarterly, Volume 13, Issue 1, pp. 27-27. In Persian

Gharakhloo, Mehdi; Panahande-Khah, Musa (2009). Evaluating the Performance of New Cities in Attracting the Population of Metropolises (Case study: New Cities Around Tehran), Human Geography Research, No. 117, pp. 17125. In Persian

Monavvari, Massoud; Tabibian, Sahar (2005), Determining Environmental Factors in Locating New Cities in Iran, Environmental Science and Technology, No. 11, pp. 1-9. In Persian

Varesi, Hamid Reza; Alizadeh, Jaber; Salehi, Maryam (2011). Analysis and Evaluation of Residents' Sense of Identity in New Cities (Case Study: New Steel City), Journal of Spatial Planning Geography, No. 3, pp. 58-45. In Persian

Varesi, Hamid Reza; Azani, Mehri; Haji Hosseini, Habib (2008), An Analysis of the Situation of the New City of Ramshar (with Emphasis on Lack of Population), Journal of Isfahan University, No. 38, pp. 68-47. In Persian

Ministry of Housing and Urban Development (2016) Qom Urban Complex and Surrounding Cities, Second and Seventh Sections. In Persian

Burby, R. \& S. Weiss (2007) New Communities USA, Lexington, MA: Lexington Books.

Hui, E. C., \& Lam, M. C. (2005). A study of commuting patterns of new town residents in Hong Kong. Habitat international, 29(3), 421-437.

Johnston, R. J. (2011) Urban Residental Pattern, Bell and Sons, London.

Shin, Dong-Jin (2012), New Town Development Policy and Case Studies in Seoul Metropolitan Area, Reserch Fellow: Urban ANA Regional planning 